\title{
The Practice of Basic HR Functions in Garments Industry in Bangladesh: Focus Group Finding
}

\author{
Md. Rahat Khan ${ }^{1}$, Murshedul Arafin ${ }^{1} \&$ S. M. Khaled Hossain ${ }^{1}$ \\ ${ }^{1}$ Lecturer, Department of Business Administration, City University, Bangladesh \\ Correspondence: Md. Rahat Khan, Department of Business Administration, City University, Khagan, Ashulia, \\ Dhaka, Bangladesh, E-mail: rahatkhan.mrk14@gmail.com
}

Received: May 11, 2017

Accepted: June 5, 2017 Online Published: August 3, 2017

doi:10.5539/jms.v7n3p120

URL: http://doi.org/10.5539/jms.v7n3p120

\begin{abstract}
A Focus Group Discussion has been made to see the practice of basic HR functions ingarment industry in Bangladesh. 13 garments employees along with the researchers in total 16 members were consisted for the FGD and the finding shows the prime reasons for the deviation of HR practice in different areas are attract foreign buyers, enhancing the brand value of the organization, employee-management relationship, cost minimization pressure, keep environment green, auditing policy compliance. Few factors have also been sort out under the four basic HR functions; those are employment planning, job advertisement, and recruitment \& selection practice, orientation, training \& development facilities, career development, job security, better salaries, appraisal systems, different leave policies, work environment, health \& safety issues, transport facilities, working hour. A quantitative analysis has also been conducted by using those identifing factors from 150 employees' responses. The study conducted the reliability test to find out the consistency of the data. Then the study shows the descriptive analysis of mean response \& Std. deviation of responses. Finally the study goes for correlation analysis for those four HR functions and the result shows the relationships among the all the functions are strongly positively correlated to each others.
\end{abstract}

Keywords: HR practice, HR functions, garment industry, focus group, correlation, Bangladesh

\section{Introduction}

The practice and implementation of HR functions is a contemporary issue in RMG (Ready Made Garments) industry in Bangladesh. Lots of questions were being asked in several studies \& conversation. RMG is one of the booming economic sectors in Bangladesh economy. Many scholars recommended nursing this sector with proper care for the betterment of the Bangladesh economy. HRM (Human Resource Management) can be considered in two important ways. One way is; HRM is thought as supportive function for staff in every organization which assists the HRM related issues to line employees. The other way is; HRM is the function of all the managers' job that means managing organization's employees effectively and efficiently. (DeCenzo\& Robbins, 2015) Effectively explains "doing the right thing" where efficiently refers "doing the thing right". (Robbins \& Coulter, 2011)

The study assumed that a bulky percentage of the garments employees are not satisfied to their current job in the RMG sector. The amount of wages they earned causes noteworthy displeasure for workers in the RMG industry The RMG owner frequently refutes that they have the capacity to increase laborers' circumstances or wages. (Morshed, 2007) Another study run on investigate the HR practice in Bangladeshi garments industry. The presumption is better practice of HR policies ensure better firm performance. The study exposed that, the HR policies are being handled very much ordinarily (Anonymous, 2012). Majumder\&Anwara (2000) found that although the reality is that garments industry matches in with the prescribed division; the staffing technique is to a vast degree casual contrasted with the practice in western. Since there have nothing agreement or formal letter, several garments workers are become helpless against losing jobs instantly without having any notice. Moreover, sexual harassment related issues in this industry is accountable for creating job uncertainty, uneven wage payment, deficiency of least amount of wage and endorsement policy. Reality is been contrasted with the other industries in Bangladesh. The unsteadiness of work in RMG sector is higher.

Mamun\& Islam (2001) investigated the HRM practices in RMG segment. The research pointed on increasing efficiency in pieces of clothing specialists by using justifiable HRM practices to chase the challenges of 
globalization. The study found that, reasons behind the workers' low efficiency is nothing but the chaotic staffing and selection of employees, nonexistence of training \& development facilities, insufficient financial supports, and low motivation level. Majumder (1998) He has pointed that, work zones are frequently crowded with restricted work places, bringing about word related dangers such as physical turmoil and infectious infirmities.Alam (2004) has sorted out that, restless work schedule, wage related penalties, and substantial \& oral abuses are common issues. Female workers face substantial abuse and unsuitable behavior within and moreover outer surface of the firm; nevertheless management does not assurance the safety of female employees. Another study revealed that, the working condition in Bangladesh RMG sectors is below the standard. Wellbeing and security policy, as suggested in 1979 Rules regarding Factory operations are routinely ignored by administration as well as government. (Absar, 2006) Kumar (2006) said that, Garments workers are concerned with extensive working periods or double chronological shifts, risky workplace, bad working environments, payment and sexual isolation.

The research is designed as following patterns; the second section covers some closely related literatures regarding HR practices. After that the third section covers the purpose \& methods of the research. The fourth section shows general research framework and FGD (Focus Group Discussion) questions \& findings. The experimental result reveals after the FGD findings along with the data interpretation. Finally the last section exposes the recommendations and concludes with ending remarks.

\section{Related Literatures}

Many studies have been conducted to explore the HR practice and implementation throughout the world in various organization \& management related sectors along with RMGs as well. HR practices have remarkable association with hierarchical responsibility and employee turnover. (Billahet et al., 2009) Rab (1991) explored the HRM practices in 24 small ventures functioning in Dhaka. He differentiate that in terms of recruitment, respondent interaction was the crucial means (58\%) lagged by advertisement in daily newspaper (21\%), walk-in interview (13\%), and notice board of organization (8\%). All of the ventures, with the exclusion of one organization, utilized work sample testing and interviewing for employees' selection.

Another study to investigate on Khulna Hard Board Mills Ltd about the overall work force management (HRM) practices. It analyzed about the recruitment policies, selection procedures, training and development program, compensation management, relationship between management \&labor, and the safety and health issues. The investigator revealed miscellaneous problems recognized with administration practices for staffs, for instance, collision in faculty division, unstable supervision range, faulty assessment, high proportion of hostile sentiment neighborhoodlaborers, non-attendance, poor programs for preparation, lack of aptitude assessment, favoritism and preference in workers' progression and choice, poor contemporary relationships, insufficient remuneration, and poor welfare and wellbeing supervisions. (Taher, 1992) Medcof\& Song (2013) Human resource (HR) applications for employee selection, performance evaluation, connection between training and performance-compensation are discovered as less categorized in entrepreneurial HR arrangements (exploratory) than in supportive HR arrangements (exploitative).The outcome expresses, HR methods and implication should diverse in dainty of the organizational procedures in which those are being functioned. Shelly (1994) scrutinized the functions of HR base on the procedure of industrialization in Bangladesh. He inspected that insufficient Human Resource Management (HRM) exercise was one of the factual problems confronted by industrial zone of Bangladesh. A bulk portion of the HR implications, for example, HR positioning, organization, determination, progression, execution assessment, remuneration, motivations, and contemporary relationships were not executed justifiably in commercial organizations.

The progress of learning orientation is checked as a managerial responsibility but HR policy makers can play a crucial role in the endorsement of learning by boosting the more conventional HR practices towards the feat of organizational successes (Gardiner \& Sadler-Smith, 2001). Islam (2003) A study on miniature organizations' HRM practices of Bangladesh. Result showed that small ventures did not provide rational pay rates and compensation, training \& development facilities to their workers. The researcher pointed out that the reason of old trait HR rehearses, the success and encouragement level of the respondents of those Bangladeshi small ventures were low.

Ozola (2014) the purpose of the exploration was to detect the HRM practices which are effective for the dropping of employee turnover. For this resolution the approaches of document study and expert analysis were used. On the base of exploration of the scientific works reclaimed from academic databases the HRM practices, stated in linkage with worker turnover, were noticed and defined its effect on worker turnover. By guiding two distinct expert investigations, the preliminary information about the extent of some known HRM practices and about the possible effectiveness of those practices in organizations of Latvia, is developed and studied. In last 
40years, study on recruiting employee has increased drastically. The paper observes the study on recruitment issues that have received substantial consideration (e.g., recruiting techniques, accurate job performances). It also addresses topics (e.g., aimed recruitment, the spot visit) that have established relatively low attention but which have the probability to be pretty significant. In exploring these issues, the variables of job applicant (e.g., self-insight), that should impact how a boss conducts the recruiting procedure but that have regularly been mistreated, are narrated. Throughout the research, significant areas for future exploration are recommended. (Breaugh, 2008) In an investigation of HR practice in Lebanese hospitals of a group of 96 respondents from 61 various hospitals. The result disclosed that, the most commonly responded challenge was weak employee maintenance (56.7\%), limitations of experienced personnel (35.1\%), and short of proper performance appraisal system (28.9\%). A little number of strategies utilized to alleviate the mentioned challenges consisted with offering continuous training \& education for employees (19.6\%), upgrading salaries (14.4\%), and developing maintenance strategies (10.3\%). Difference between strategies \& responded challenges were detected. (El-Jardali et al., 2009)

Zhu et al. (2008) in a study of 618 managers, employed in state-owned enterprises, foreign-invested, and domestic/private firms running at the Jiangsu Province in China; explores the degree to which Human Resource practices have been strategically development to line/middle managers and the affiliation between this development and those firms' performance. On the whole, there was little substantiation of devolvement to line or middle managers and found no substantiation of an association between the performance of firm and the extent of devolvement, though the provision of official training to middle or line managers was predictive of performance. Different categorized fifteen industries in India (such as, automobiles, chemicals, gas, infrastructure, metal, mining, oil, power etc) that use best HR practice were selected for the study. The paper tried to estimate whether all the selected organizations have same manner of HR practice or not and their relevant corporate strategy was classified as focusing quality, reducing cost, and flexing the systems. (Tomar, 2011)

The above literatures reviewed the HR practice in many managerial sectors both the Bangladesh and foreign countries. Based on this literatures the study explore the HRM (Human Resource Management) practices \& implementation in garments industry of Bangladesh by using the four HR functions as, staffing, training \& development, motivation, and maintenance proposed by DeCenzo\& Robbins and provide some guidelines to the concerned authority for improving the existing circumstance of human resource management practices \& implementation in garments industry of Bangladesh.

\subsection{HR Functions}

Armstrong (1997), Human Resource Management can be defined as "a strategic approach to acquiring, developing, managing, motivating and gaining the commitment of the organisation's key resource-the people who work in and for it." HRM deals with concerns related to human resources such as hiring, training \& development, compensation, motivation, communication, and administration.(Patidar, 2014) HR experts in each discipline may execute more than one of the more than six vital functions such as recruitment, safety, employee relations, compensation \& benefits, compliance, and training \& development. (Mayhew, 2017)

Mooney (2017) The HRD deals many crucial functions in business. It is influential in given that labor law compliance, record keeping, hiring and training, compensation, relational assistance and assists with handling specific performance topics. The HRM holds out three separate functions such as a line functions, a coordinative functions, and staff functions. (Dessler\&Varkkey, 2011) The functions execute by managers are familiar to all organizations. For the handiness of study, the function execute by the resource management can roughly be categorized into two categories Managerial functions (staffing, directing, and controlling), and Operative functions (Procurement, Development, Compensation, and Maintenance). (Chand, 2016)

To look at HRM more expressly recommend that it consists of four fundamental functions staffing, training and development, motivation, and maintenance. That might say that HRM is contained of four activities like hiring people, preparing them, stimulating them, and keeping them. (DeCenzo\& Robbins, 2015)

\subsection{Ready Made Garments (RMG) Industry in Bangladesh}

Bangladesh Investment Development Authority (2017) the unique growth in the (RMG) sector in the previous decade generated many latest factories and employment opportunities. Having pleasured more than $70 \%$ of total outlays in the manufacturing sector throughout the first six months of the 1990s, RMG and knitwear now having about 4,825 factories and a labor force of 3.1 million out of them $80 \%$ are women. This sector now occupies over $50 \%$ of the manufacturing workforce and having $79 \%$ of the total export incomes of the country. The upward trend in the textile and the garments sector denotes that Bangladesh is flawlessly placed to appeal to foreign patrons. 
(RMG) sector of Bangladesh has risen as the biggest receiver of foreign currency. This sector generates about 4.2 million employment openings and adds significantly to the GDP. RMGs of Bangladesh are muscled by young, urbanizing, workers, where the majority of them are women. (Kiron, 2015) The readymade garments industry performs as the spine of Bangladesh economy and as a means for the growth of the country. Nation and the civilian take pride in the sector that has been brought billions of dollars as export incomes and producing jobs for millions of individuals in the country. (Hassan, 2014)

Rahman (2015) while all main garment products exporters like Italy, Turkey, France, Belgium, China, South Korea, etc lost export steam since 2008 because of the worldwide downturn particularly in their export intentions in spite of having privileged entrance and geographical closeness, Bangladesh not only upheld its past gains, but also enhanced its performance drastically during both the post-MFA (Multi-Fibre Arrangement)and recession periods. This astonishing growth of the Bangladesh RMG sector could be credited to nonstop support from its government, lowest pay rate, lesser export price, accompanied by steady exchange rate and political firmness.

\section{Purpose}

The researchers selected focus group study to observe the current situation regarding HR practice of garment sectors in Bangladesh then structured a questionnaire on the basis of FGD to justify the participants' opinions. In details, the basic reason is to see the HR practice and implementation tendency by the authorities in case of garments sector. The study paid attention on that practice in two areas; especially in EPZ (Export Processing Zone) areas and outside the EPZ areas. The researchers tried to show descriptive statistics of the quantitative response regarding HR practice by using the mean, standard deviation \& variance of responses, after that they tried to show the correlation of the HR functions on the basis of respondents' answers.

\section{Methods}

This study is based on both the qualitative \& quantitative research. During qualitative study the research used the Focus Group Discussion (FGD) technique. After the discussion the researchers will prepare a questionnaire and go for survey. The detailed study framework is sated below.

\subsection{Research Design}

The FGD is a swift evaluation, semi - ordered data collecting method in which a reasonably chosen set of attendants meeting to converse matters and thoughts based on a directory of crucial topics drawn up by the researcher/catalyst (Kumar, 1987).

This qualitative research method was initially developed to provide marketing researchers a better valuing of the data from quantitative surveys of consumers. As an essential instrument for researchers in marketing field (Krueger, 1988)

After the FGD, this study conducted for exploratory research. Exploratory studies are an important method for discovering "what is going on; to look for new bits of knowledge; to make inquiries and to survey marvels in another light" (Robson, 2002).

\subsection{Sample}

Sample Size for FGD: To review the current situation the researchers conducted a FGD; 13 employees were invited having various designations from five garments both in the EPZ \& Non-EPZ areas and the researchers, in total 16.

Sample for Quantitative Analysis:Some Structured questions were being asked to the FGD members. After the FGD discussion results, another questionnaire had been made to survey. Due to time and budget constraint the study is conducted on 150 employees from ten garments in EPZ \& Non-EPZ areas in Bangladesh. From each garment 15 persons are randomly selected as sample size. For more than 50,000 numbers of population, at confidence interval of $\pm 10 \%, \mathrm{~N}=100$; confidence interval of $\pm 5 \%, \mathrm{~N}=400$ (Conroy, 2015); sample size $\mathrm{N}=88$, Margin for random error $\pm 10 \%$, and sample size $N=350$, Margin for random error $\pm 5 \%$ (Fox et al., 2007). The study considered 36 assistant managers, 16 deputy managers, 14 managers, 10 Sr. managers, 7 AGMs, 3 DGMs, 33 machine operator, $21 \mathrm{sr}$. technician, 8 quality inspector, 2 finishing in-charge.

After this FGD the researchers made a structured questionnaire for quantitative research based on discussion. The questionnaire had been prepared under four basic functions of HRM proposed by S.P Robbins. The structured questionnaire is given in Apeendix-1.1

The study used a variety of statistical tools such as reliability test, weighted average, standard deviation, arithmetic means etc. are used for processing the data. SPSS software version 16 was used to analyze the data, reliability test, demographic statistics analysis, and correlation. 
Before analyzing the collective data the study conducted a reliability test to find out the consistency of the data.

If $\alpha<.50$ to .69 which means poorly consistent; if $\alpha<.70$ to .79 which means fairly consistent; if $\alpha<.80$ to .89 which means goodly consistent; and if $\alpha<.90$ to .99 which means strongly consistent (Taylor, 2013; Cortina, 1993; Kline, 2000; George \&Mallery, 2003).

\subsection{The Study Instrumentation}

The study was framed with the assistance of primary data. To understand the HR practices and implementation in RMG sector the research primarily find out the basic functions (Staffing, Training \& Development, Motivation and Maintenance) of human resource division of an organization (DeCenzo\& Robbins, 2015).

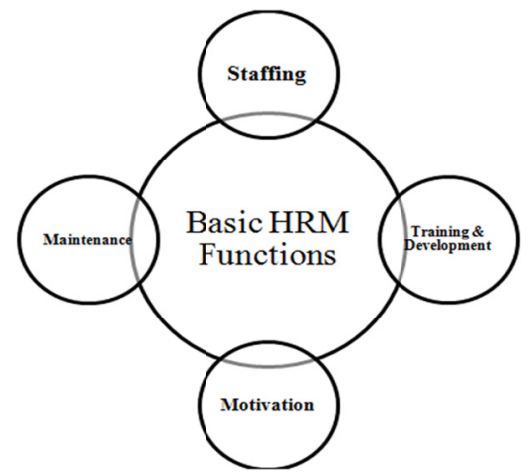

Figure 1. Basic HRM functions (considered for this research framework) (DeCenzo \& Robbins, 2015)

The questionnaire was designed after the discussion from FGD and 16 questions was set under the four HR function and each question is considered as variables for the research. The data was collected through questionnaire from the Garment employees from various levels. A Five Point Likert Scale was used for the study; which denotes 1 as "Strongly Disagree", 2 as "Disagree", 3 as "Indifferent", 4 as "Agree" and 5 as "Strongly Agree" (Sullivan \&Artino, 2013).

\section{Data Analysis}

The study starts with a Focus Group Discussion by 13 employees from different garment factory along with the three researchers. The following table will show the FGD participants' (Employees) demographic characteristics.

Table 1. Focus group participants' data \& profile

\begin{tabular}{|c|c|c|}
\hline Demographic Characteristics & Frequency & Percentage $(\%)$ \\
\hline \multicolumn{3}{|l|}{ Gender $(n=13)$} \\
\hline Male & 11 & 84.52 \\
\hline Female & 2 & 15.38 \\
\hline \multicolumn{3}{|l|}{ Year of Experience $(n=13)$} \\
\hline $0-1$ Year & 3 & 23.08 \\
\hline $1-2$ Years & 1 & 7.69 \\
\hline 2-3 Years & 1 & 7.69 \\
\hline 3-4 Years & 0 & 0 \\
\hline 4-5 Years & 1 & 7.79 \\
\hline Above 5 years & 7 & 53.85 \\
\hline \multicolumn{3}{|l|}{ Management Level (n=13) } \\
\hline Lower Level & 3 & 23.08 \\
\hline Middle Level & 10 & 76.92 \\
\hline \multicolumn{3}{|l|}{ Working Zone (n=13) } \\
\hline EPZ Area & 8 & 61.54 \\
\hline Non-EPZ Area & 5 & 38.46 \\
\hline \multicolumn{3}{|c|}{ Designation of FGD Members $(n=16)$} \\
\hline & Frequency \\
\hline \multicolumn{2}{|l|}{$\begin{array}{c}\text { Profile of Participants }(n=16) \\
\text {. Researchers }\end{array}$} & 3 \\
\hline \multicolumn{2}{|c|}{ - $\quad$ Manager (Industrial Engineering) } & 1 \\
\hline \multicolumn{2}{|c|}{ - $\quad$ Asst. Manager (Industrial Engineering) } & 1 \\
\hline
\end{tabular}




\begin{tabular}{lll}
\hline - & Manager (Cutting) & 1 \\
- & Manager (Manager (Merchandising) & 1 \\
- & Manager (Knitting) & 1 \\
- Asst. Manager (Merchandising) & 1 \\
- & Asst. Merchandiser & 1 \\
- & Production manager & 1 \\
- & Asse Chistant Quality Supervisor & 1 \\
- Welfare Officer & 1 \\
\hline
\end{tabular}

A set of questions was asked for qualitative research to review the current situation. In Table2 the set of questions is stated for FGD

Table 2. Questions for focus group

1. Hope all of you know about HR practice. Lots of discussions have been discussed by the civilian regarding this particular issue especially in this garment sector in Bangladesh. Today we will discuss about this issue. Briefly I would like to introduce about the basic four functions about HRM (Proposed by S.P Robbins); hope almost every one of you knows about this, because all of you having business degree.

a) What about the staffing practice situating in your organization? Is that fare or not by your own judgment, briefly clarify please?

b) Would you please share us about training \& development activities in your organization? Is that effective for employees for further improvements?

c) Is there any motivational activities exist in your organization? Which types of activities; financial, nonfinancial, or both?

d) What types of attitude are been shown by the authority towards the experienced or seniors employees regarding maintenance functions?

2. Now let us clarify about the variation of your response. What are basic reasons for the variation of HR practices? Is there any location implication, organizational policy or both?

a) Why the practice is properly utilized in EPZ areas?

b) What are the main reasons for neglecting these HR practices in Non-EPZ areas?

3. Dear participants please share some effective and positive opinions regarding the variation of HR practices.

a) Is there any strict bureaucratic policy needed for improvement in Non-EPZ areas like the EPZ zone?

b) What will you do to resolve these imbalances?

\subsection{FGD Findings}

There are some important issues have been come out in FGD. The major findings are:

- The govt. roles \& regulations are strictly maintained in those garments which are located in EPZ areas garments rather than the Non-EPZ areas.

- In staffing practice the factors are come out as (a) Employment Planning (b) Job Advertisement (c) Recruitment \& Selection practice.

- In case of training \& development functions the following factors are find out (a) Orientation (b) Training \& Development facilities (c) Career Development.

- (a) Job Security (b) Better Salaries (c) Appraisal Systems (d) Different Leave policies are short out under motivational elements.

- Under maintenance function (a) work environment (b) Health \& Safety issues (c) Transport Facilities (d) working hour are found out.

The prime reasons for the differentiation of HR practice in different areas are sort out as (1) Attract foreign buyers (2) Enhancing the brand value of the organization (3) Employee-Management Relationship (4) Cost Minimization Pressure (5) Keep Green Environment (6) Auditing Policy compliance. Each of the above issues will be discussed in upcoming parts.

\section{A. Attract Foreign Buyers}

The concept has been found from focus group discussion that the garment factories of EPZ areas strictly follow the HR function due to attract their current foreign buyers as per their instructions. Basically the foreign buyers have some restriction or threat to maintain the proper HR practices \& other related activities than the Non-EPZ areas. 


\section{B. Enhancing the Brand Value of the Organization}

This is another concept has been arisen from the focus group that for maintaining the brand value of the firm the management decides to keep better HR practice in EPZ areas. In case of Non-EPZ areas the quality local/foreign buyers are less than the EPZ areas that is another reason for the differences. However, some factories located in Non-EPZ areas also maintain good HR practice.

\section{History Employee-Management Relationship}

Another factor for the differentiation of HR practice from organization to organization is the history of employee-management relationship. Few organizations want to keep better relationship between employees \& management for long-run commitment. This is also observing that, the firms which maintain good relationship have better revenue generation than the others.

\section{Cost Minimization Pressure}

This is another factor has been sort out from FGD. Sometimes the buyers have some cost minimization pressure to the producers. To maintain the buyers' requirements the garment firms try to reduce the cost from different areas. For that particular reason the producing garment firms cannot be maintained HR practice properly.

\section{E. Keep Green Environment}

This is another reason for the differences of HR practices from garment firm to firm. Few garment firms have some interest to keep green environment. Few FGD members also point out that few buyers have some interest on those garments which maintain green environment even that concept can be used as advertising tool for attracting the buyers.

\section{F. Auditing Policy Compliance}

This is last but not the least discussing factor regarding HR practice deviation from garment firm to firm is better auditing policy compliance. For keeping the firm free from any hazards regarding auditing policy form the author. Few garments properly maintain the HR practice for good rating or credit.

Table 3. Reliability statistics of data

\begin{tabular}{lll}
\hline Reliability Statistics & & \\
HR Functions & Cronbach's Alpha & No. of Items \\
\hline Staffing Practice & .603 & 4 \\
Training and Development facilities & .751 & 4 \\
Motivational factors & .578 & 4 \\
Maintenance issues & .617 & 4 \\
\hline
\end{tabular}

So the above reliability statistics (table3) shows that, responding data pass the reliability testing and the data are consistent for the study

\subsection{Descriptive Statistics}

\subsubsection{Demographic Characteristics of Data}

Table 2 depicts the descriptive statistics. Out of 150 employees, about three fourth of the sample is male, and the rest are female. Majority of the employees are in 36-45 ages group which depicts $38 \%$ then $30 \%$ are in $26-35$; $21.33 \%$ in $46-55$ range; above 55 are only 12 persons; and 4 workers having the age range of $18-25$. The year of experiences of the respondents are mixed, most of them 2-3 years of experiences in garments sector; 20 out of 150 respondents having more than 5 years of experience in this particular sector. 
Table 4. Demographic characteristics of data

\begin{tabular}{lll}
\hline Demographic Characteristics & Frequency & Percentage (\%) \\
Gender $(\mathbf{n = 1 5 0 )}$ & 118 & 78.7 \\
Male & 32 & 21.3 \\
Female & 4 & 2.67 \\
\hline Age Group $(\mathbf{n = 1 5 0 )}$ & 45 & 30 \\
$18-25$ & 57 & 38 \\
$26-35$ & 32 & 21.33 \\
$36-45$ & 12 & 8 \\
$46-55$ & & \\
Above 55 & 17 & 11.3 \\
\hline Year of Experience $(\mathbf{n}=\mathbf{1 5 0})$ & 21 & 14.0 \\
0-1 Year & 43 & 28.7 \\
1-2 Years & 31 & 20.7 \\
2-3 Years & 18 & 12.0 \\
3-4 Years & 20 & 13.3 \\
4-5 Years & & \\
Above 5 years & 64 & 42.67 \\
\hline Management Level $(\mathbf{n}=\mathbf{1 5 0})$ & 86 & 57.33 \\
Lower Level & & 48 \\
Middle Level & 72 & 2.67 \\
\hline Education Level $(\mathbf{n}=\mathbf{1 5 0})$ & 4 & 32 \\
Up to College & 48 & 17.33 \\
Diploma Holder & 26 & \\
Bachelor Degree & & \\
Master Degree & & \\
\hline
\end{tabular}

From the above table no top level management was asked regarding the issue and majority respondents are middle level worker with having of $57.33 \%$; rest of them are bottom level workers. In case education level $48 \%$ having up to college level degree, basically those are working as bottom level. 32\% have bachelor degree and 26 personnel having master degree or equivalent. A few respondents have diploma degree.

\subsubsection{Descriptive Statistics of Data}

The mean responses of staffing factors are $2.42,2.61,2.64$, and 2.78 out of 5 respectively for planning, advertising, recruiting, and selection. And the standard deviation (SD) of the responses is 1.018, 1.29, 1.172, and 1.263 respectively for planning, advertising, recruiting, and selection.

Table 5. Descriptive statistics of data

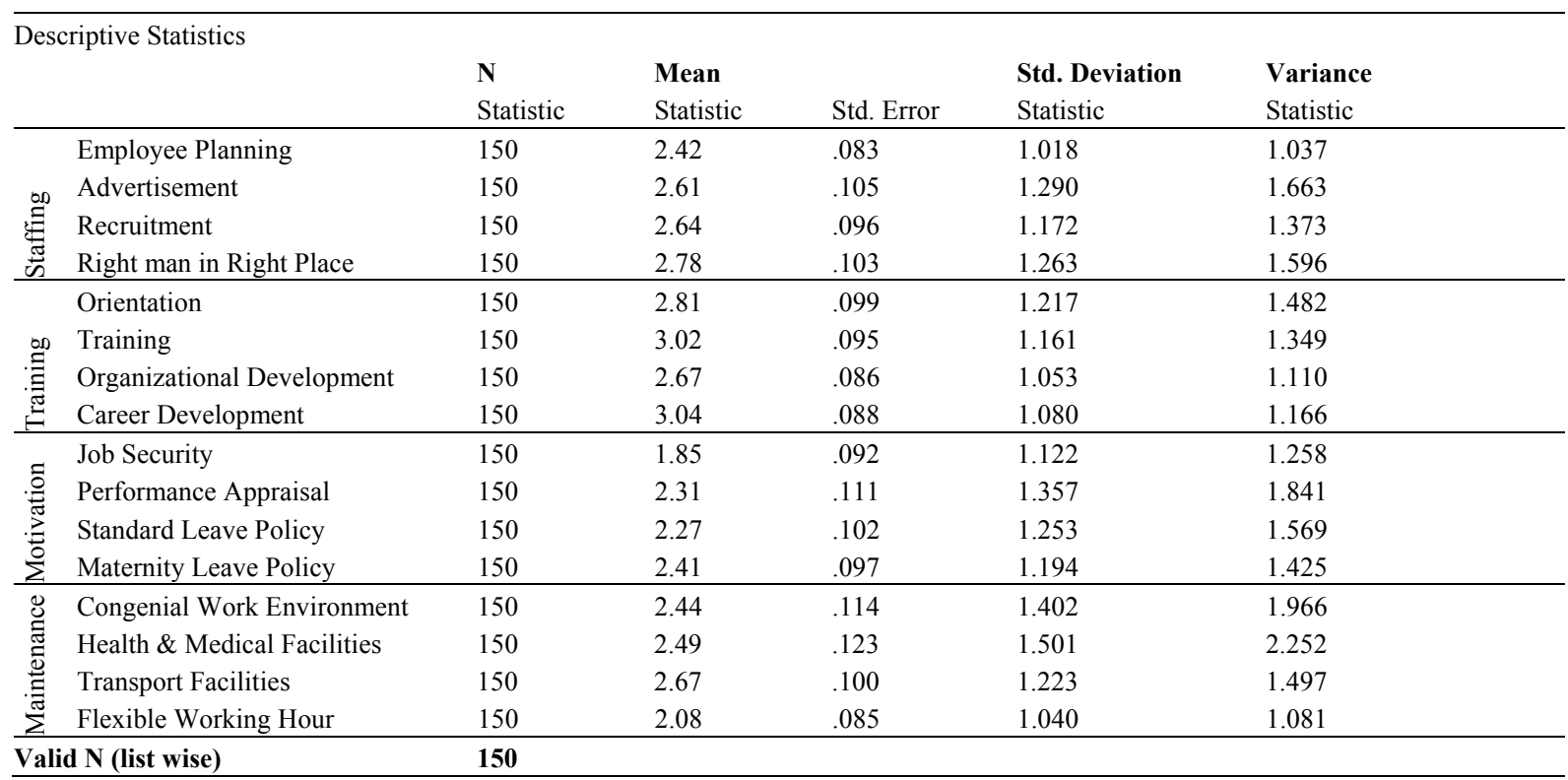


[N.B: These above factors have been set after analyzing\& combining the FGD findings and S.P. Robbins' Human Resource Management: Primary Activities]

The mean responses of training factors are 2.81, 3.02, 2.67, and 3.04 out of 5 respectively for orientation, training, organizational development, and career development. And the standard deviation (SD) is 1.217, 1.161, 1.053 , and 1.080 respectively for orientation, training, organizational development, and career development.

In case of motivation factor, the respondents are roughly disagree abouttheir job security with having 1.85 of mean response and 1.122 of SD rest of the factors' mean response are 2.31 \& SD is 1.375 for performance appraisal, 2.27 from leave policy \& SD is 1.253 and 2.41 for maternity leave policy with having the SD of 1.194.

Finally for the maintenance function the respondents ticked at 2.44 for work environment, 2.46 for health \& medication, 2.67 for transport, and 2.08 for working hour with having 1.402, 1.501, 1.223, and 1.040 Std. deviation respectively.

\subsection{Correlation Table Explanation}

By using Likert 5 point scale regarding different factors of HR functionsthe following table shows all the four HR functions are strongly positively correlated to each other. The correlation between Staffing and Training is 0.963 which is significant at 0.01 level. The correlation between staffing and motivation is 0.965 which is also significant at 0.01 level. The correlation between staffing and maintenance is 0.975 and significant at $1 \%$ level.

Table 6. Correlations of the responding data for the selected HR functions

\begin{tabular}{llllll}
\hline Correlations & & Staffing & Training & Motivation & Maintenance \\
\hline Staffing & Pearson Correlation & 1 & $.963^{* *}$ & $.965^{* *}$ & $.975^{* *}$ \\
& Sig. (2-tailed) & & .000 & .000 & .000 \\
& $\mathrm{~N}$ & 150 & 150 & 150 & 150 \\
\hline Training & Pearson Correlation & $.963^{* *}$ & 1 & $.951^{* *}$ & $.968^{* *}$ \\
& Sig. (2-tailed) & .000 & & .000 & .000 \\
& $\mathrm{~N}$ & 150 & 150 & 150 & 150 \\
\hline Motivation & Pearson Correlation & $.965^{* *}$ & $.951^{* *}$ & 1 & $.982^{* *}$ \\
& Sig. (2-tailed) & .000 & .000 & & .000 \\
& $\mathrm{~N}$ & 150 & 150 & 150 & 150 \\
\hline Maintenance & Pearson Correlation & $.975^{* *}$ & $.968^{* *}$ & $.982^{* *}$ & 1 \\
& Sig. (2-tailed) & .000 & .000 & .000 & \\
& $\mathrm{~N}$ & 150 & 150 & 150 & 150 \\
\hline **. Correlation is significant at the 0.01 level (2-tailed). & & & \\
\hline
\end{tabular}

The correlation between training \& motivation is 0.951 and the result is significant at 0.01 level. The correlation between training \& maintenance is 0.968 and it's significant at 0.01 level. Finally the correlation between Motivation \& maintenance is 0.982 which is also significant at $1 \%$ level of significance.

\section{Conclusion}

A plenty of researches have been explored to know how the managerial activities are going on RMG sectors in Bangladesh in recent past. This particular research has been conducted to see the practice of basic HR functions \& its deviation from garments to garments in Bangladesh. The study went through a FGD; where 13 employees along with researchers in total 16 members were in FGD. A structured set of questions were being asked to the participants and the result shows the prime reasons for the deviation of HR practice in different areas are attract foreign buyers, enhancing the brand value of the organization, employee-management relationship, cost minimization pressure, keep green environment, auditing policy compliance.

After the FGD few factors have been found under each for HR functions (Proposed by DeCenzo\& Robbins). In staffing practice the factors are come out as employment planning, job advertisement, and recruitment $\&$ selection practice. In case of training \& development functions the following factors are find out orientation, training \& development facilities, career development. Job security, better salaries, appraisal systems, different leave policies are short out under motivational elements. Under maintenance function work environment, health \& safety issues, transport facilities, working hour are found out.

For descriptive analysis, 150 employees were selected as the respondents. The study firstly runs the reliability test to find out the consistency of the data. Then show the descriptive analysis of mean response \& Std. deviation of 
responses. Finally the study goes for correlation analysis for those four HR functions and the result shows the relationships among the all the functions are strongly positively correlated to each others.

However, the investigation has some limitations. 13 employees for FGD can be raised for strengthen the result. For quantitative analysis, 150 employees from 10 garments have been picked up. The study can be more extensive if the sample size and investigating factories would more than the selective sample. Moreover the grievance and responses of mid-level employees are not same for the grievance and responses of lower level employees. In addition the study focuses on Dhaka Zone it could be better observation if the research could run in EPZs \& Non-EPZ areas across the country. In addition, only sixteen factors are found under the all four functions thereby more factors may be considered to bring dynamic \& diversified results in near future. In future more studies can use more statistical tools like factor analysis, t-testing, regression analysis and so on as per the situation will demand.

\section{References}

Absar, M. M. N., \&Mahmood, M. (2011). New HRM practices in the public and private sector industrial enterprises of Bangladesh: A comparative assessment.International Review of Business Research Papers, 7(2), 118-136.

Absar, S. S. (2009). 2.7 Problems surrounding wages: the readymade garment sector in Bangladesh.Labour and Management in Development, 2.

Alam, M. J., Mamun, M. Z., \& Islam, N. (2004).Workplace Security of Female Garments Workers in Bangladesh.Social Science Review, 21(2), 191-200.

Anonymous. (2012). A study on: HRM practices in Garments Industries and its Impact. World24info.Retrieved from http://world24info.blogspot.com/2012/02/research-study-on-hrm-practices-in.html

Armstrong, M. (1997).Armstrong's essential human resource management practice: A guide to people management. London: Kogan Page Publishers.

Billah, M., \& Islam, S. (2009). Human resource management practices and organizational Commitment: A survey on private commercial banks in Bangladesh. Southeast University journal of Business Studies, 5(1), 153-166.

Breaugh, J. A. (2008). Employee recruitment: Current knowledge and important areas for future research. Human Resource Management Review, 18(3), 103-118. https://doi.org/10.1016/j.hrmr.2008.07.003

Chand, S. (2016).Human Resource Management: Meaning, Objectives, Scope and Functions. Retrieved fromhttp://www.yourarticlelibrary.com/hrm/human-resource-management-meaning-objectives-scope-and-f unctions/35229/

Cortina, J.M. (1993). What is coefficient alpha? An examination of theory and applications.Journal of Applied Psychology, 78, 98-104.https://doi.org/10.1037/0021-9010.78.1.98

Creative HRM.(2012). History of Human Resources Management.Retrieved from http://www.creativehrm.com/hr-management-history.html

Davidson, W. L. (1979). How to develop and conduct successful employee attitude surveys. Dartnell.

DeCenzo, D. A., Robbins, S. P., \&Verhulst, S. L. (2015). Fundamentals of human resource management:HRM Functions and Strategy. New York: Wiley Global Education.

Dessler, G. (2009). A framework for human resource management.Pearson Education India.

Dessler, G., \&Varkkey, B. (2011). Human resource management India: Dorling Kindersley.

El-Jardali, F., Tchaghchagian, V., \& Jamal, D. (2009). Assessment of human resources management practices in Lebanese hospitals. Human resources for Health, 7(1), 84. https://doi.org/10.1186/1478-4491-7-84

Fox, N., Hunn, A., \&Mathers, N. (2007). Sampling and sample size calculation. The NIHR RDS for the East Midlands/Yorkshire \& the Humber.

Gardiner, P., Leat, M., \& Sadler-Smith, E. (2001). Learning in organizations: HR implications and considerations. Human Resource Development International, 4(3), 391-405.https://doi.org/10.1080/13678860126433

George, D., \&Mallery, P. (2003).SPSS for Windows step by step: A simple guide and reference. 11.0 update (4th ed.). Boston: Allyn\& Bacon.

Haque, M. M., \&Taher, M. A. (2008). Job Characteristics model and job satisfaction: Age, gender and marital status effect. In 7th International Conference on Ethics and Quality of Work-life for Sustainable 
Development, Bangkok, Thailand.

Hassan, F. (2014).RMG industry of Bangladesh: Past, present and future. Retrieved from http://archive.dhakatribune.com/long-form/2014/sep/19/rmg-industry-bangladesh-past-present-and-future

$\mathrm{http}: / /$ hrmpractice.com/basic-functions-human-resource-management/

http://smallbusiness.chron.com/four-basic-skills-human-resource-management-22686.html

http://www.bida.gov.bd/site/page/c9ffe4ad-1b7e-4c85-b77e-b7d9427d4533/Garments-\&-Textiles

http://www.statsmakemecry.com/smmctheblog/confusing-stats-terms-explained-internal-consistency.html

http://www.whatishumanresource.com/the-historical-background-of-human-resource-management

https://www.researchgate.net/post/How_do_you_determine_a_sample_size_for_an_unknown_population_that_c an_state_with_a_predetermined_confidence

https://www.researchgate.net/publication/242589494_Focus_Group_Discussion_1

Kiron, M. I. (2016). Readymade Garments Industry of Bangladesh. Retrieved from http://www.garmentsmerchandising.com/readymade-garments-industry-of-bangladesh/

Kothari, C. R. (2004). Research methodology: Methods and techniques. New Age International.

Krueger, R. A. (1988). Focus groups: A practical guide for applied research. Newbury Park, California, U.S.A.: Sage Publications, Inc.

Kumar, A. (2006). Bangladesh: Industrial chaos worsens political instability. South Asia Analysis Group, Paper, (1852).

Kumar, K. (1987). Conducting focus group interviews in developing countries.A.I.D. Program Design and Evaluation Methodology Report No. 8. Washington, D.C.: U.S. Agency for International Development.

Landau, S., \&Everitt, B. (2004).A handbook of statistical analyses using SPSS. Boca Raton, FL: Chapman \& Hall/CRC.

Levin, R. I. (2008). Statistics for management.Andhra Pradesh: Pearson Education India.

Lind, D. A., Marchal, W. G., \&Wathen, S. A. (2007). Statistical Techniques in Business \& Economics with Global Data Sets.McGraw-Hill Irwin.

Line, P. (2000).The handbook of psychological testing (2nd ed., p. 13).London: Routledge.

Mamun, M., \& Islam, M. (2001). Managing women work force: A case study of ready made garments (RMGs) in Bangladesh. The Chittagong University Journal of Commerce, 16(2), 81-90.

Mayhew, R. (2017). Six Main Functions of a Human Resource Department.Retrieved from $\mathrm{http} / / /$ smallbusiness.chron.com/six-main-functions-human-resource-department-60693.html

Medcof, J. W., \& Song, L. J. (2013). Exploration, exploitation and human resource management practices in cooperative and entrepreneurial HR configurations. The International Journal of Human Resource Management, 24(15), 2911-2926. https://doi.org/10.1080/09585192.2012.756055

Mooney, L. (2017). Key Functions of an HR Department. Retrieved from http://smallbusiness.chron.com/key-functions-hr-department-31206.html

Morshed, M. M. (2007). A study on labour rights implementation in readymade garment (RMG) industry in Bangladesh: Bridging the gap between theory and practice. University of Wollongong Thesis Collection, 40.

Niluthpaul, S., Khaled, H. S., \&Kohinur, M. M. (2016). Are the Functional Factors of Human Resource Management Subsisting in the Ready-Made Garments (RMG) of Bangladesh? Theory Conflicts with Reality. International Journal of Business and Management, 11(7), 150.https://doi.org/10.5539/ijbm.v11n7p150

Ozolina-Ozola, I. (2014). The impact of human resource management practices on employee turnover. Procedia-Social and Behavioral Sciences, 156, 223-226. https://doi.org/10.1016/j.sbspro.2014.11.178

Patidar, M. (2014).Functions of Human Resource Management. Retrieved from http://www.enotesmba.com/2014/11/functions-of-human-resource-management.html

Paul-Majumder, P., \& Begum, A. (2000). The gender imbalances in the export oriented garment industry in Bangladesh. The World Bank, Development Research Group/Poverty Reduction and Economic Management Network, Washington, DC.

Rab, A. (1991). Management pattern and problems of small enterprises of Bangladesh.Journal of Business 
Administration, 17(3\&4), 34-51.

Rahman, F. S. (2015). The RMG Sector of Bangladesh: Problems and Survival Strategy. Retrieved from http://southasiajournal.net/the-rmg-sector-of-bangladesh-problems-and-survival-strategy/

Robbins, S. P., \& Coulter, M. (2011).Management (10th ed.).

Robson, C. (1993). Real world research: A resource for social scientists and practitioner-researchers.

Saunders, M., Lewes, P., \&Thornhill, A. (2011).Research methods for business students (5th ed.). Andhra Pradesh: Pearson Education India.

Shelly, M. (1994).Human resource, infrastructure, and industrialization in Bangladesh. In Seminar on Private Sector Growth: Creating Conducive Environment, Dhaka, Bangladesh.

Snell, S., \&Bohlander, G. W. (2010).Principles of human resource management.South-Western Cengage Learning.

Sullivan, G. M., \&ArtinoJr, A. R. (2013). Analyzing and interpreting data from Likert-type scales. Journal of graduate medical education, 5(4), 541-542. https://doi.org/10.4300/JGME-5-4-18

Taher, A. (1992). Personnel management practices in Bangladesh (A case study of Khulna Hard Board Mills Ltd.). Management Development, 21(1), 69-82.

Tomar, A. (2011). Effect of organizational strategy on universalistic or contingent HR practices in Indian manufacturing.Indian Journal of Industrial Relations, 306-320.

Yu, B. B., \&Egri, C. P. (2005). Human resource management practices and affective organizational commitment: A comparison of Chinese employees in a state-owned enterprise and a joint venture. Asia Pacific Journal of Human Resources, 43(3), 332-360. https://doi.org/10.1177/1038411105058706

Zhu, J. C., Cooper, B., De Cieri, H., Bruce, T. S., \& Zhao, S. (2008). Devolvement of HR practices in transitional economies: Evidence from China. The International Journal of Human Resource Management, 19(5), 840-855. https://doi.org/10.1080/09585190801991350

\section{Appendix}

QUESTIONNAIRE

QUESTIONNAIRE FOR HRPRACTICE IN BANGLADESHI GARMENT SECTOR (EPZ ZONE \& NON-EPZ ZONE)

\section{Dear Sir/ Madam,}

This questionnaire will be used to collect information regarding the HR practice in Bangladeshi garment sector. As a part of this data gathering, the information collected will be used to identify the areas needed for improvement, analyze the factors attributing to HR practice, and hopefully improve future employment prospects. All responses will be kept confidential and the results are used for academic purpose only. Kindly provide us with the following information.

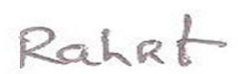

Md. Rahat Khan

Academician \& Researcher 


\section{Demographic Information}

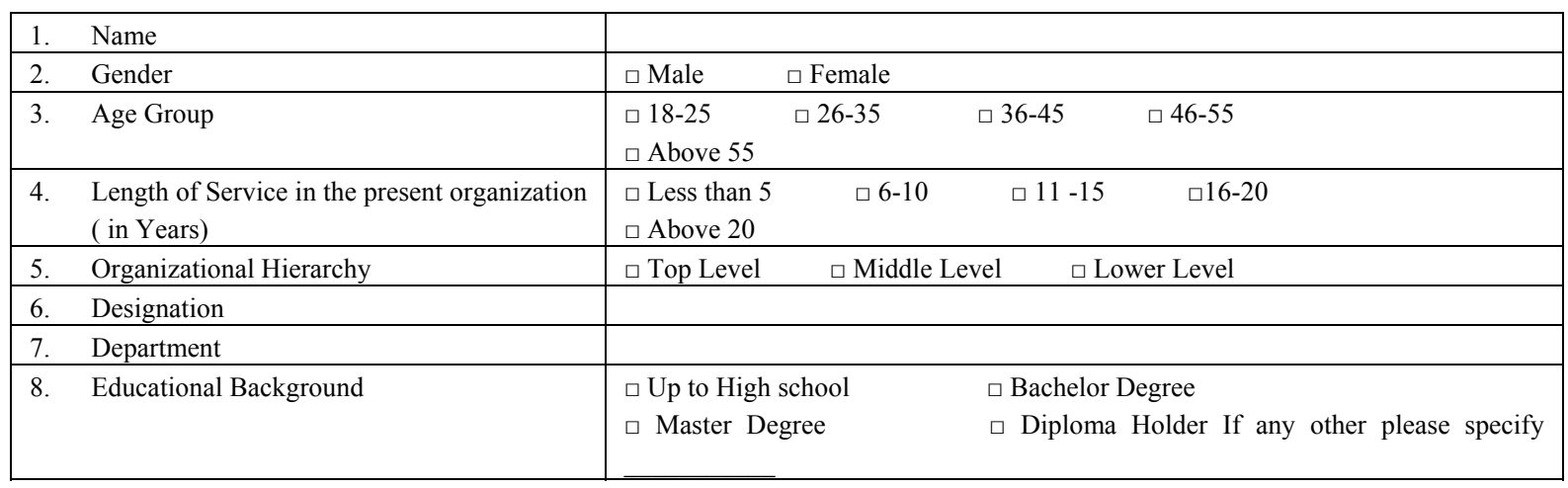

\begin{tabular}{|c|c|c|c|c|c|c|}
\hline & $\begin{array}{l}\text { This section aims to identify HR practices opinion on basis of basic HR functions proposed by S.P. } \\
\text { Robbins inBangladeshi garment sector. } \\
\text { [N.B: These following factors have been set after analyzing\& combining the FGD findings and S.P. } \\
\text { Robbins' Human Resource Management: Primary Activities] }\end{array}$ & 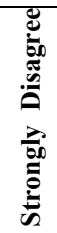 & 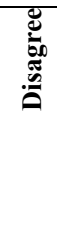 & 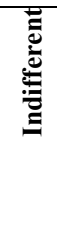 & 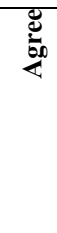 & 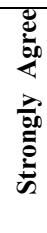 \\
\hline & & 1 & 2 & 3 & 4 & 5 \\
\hline & Staffing Function & & & & & \\
\hline 1. & Proper Employment Planning Is Exist & $\square$ & $\square$ & $\square$ & $\square$ & $\square$ \\
\hline 2. & Organization Provides Effective Job Advertisement & $\square$ & $\square$ & $\square$ & $\square$ & $\square$ \\
\hline 3. & Proper Recruiting of Candidate in Exist & $\square$ & $\square$ & $\square$ & $\square$ & $\square$ \\
\hline 4. & Right man in Right Place & $\bar{\square}$ & $\square$ & $\bar{\square}$ & $\square$ & $\square$ \\
\hline & $\begin{array}{l}\text { Training \& Development Function } \\
\end{array}$ & & & & & \\
\hline 1. & My Organization Arranges A Fruitful Orientation Program for New Employees & $\square$ & $\square$ & $\square$ & $\square$ & $\square$ \\
\hline 2. & Proper Employee Training in Provided by Organization & $\square$ & $\square$ & $\square$ & $\square$ & $\square$ \\
\hline 3. & Organization Development Facility Is Available & $\bar{\square}$ & $\bar{\square}$ & $\bar{\square}$ & $\bar{\square}$ & $\square$ \\
\hline 4. & My Organization Has Effective Career Development Facility & $\square$ & $\square$ & $\square$ & $\square$ & $\square$ \\
\hline & $\begin{array}{ll} & \text { Motivation Function } \\
\end{array}$ & & & & & \\
\hline 1. & My Organization Has High Job Security & $\square$ & $\square$ & $\square$ & $\square$ & $\square$ \\
\hline 2. & Proper Performance Appraisal System Is Exist & $\square$ & $\square$ & $\square$ & $\square$ & $\square$ \\
\hline 3. & Standard Leave Policy Is Offered & $\square$ & $\square$ & $\square$ & $\square$ & $\square$ \\
\hline 4. & Maternity Leave Policy Is Offered & $\square$ & $\square$ & $\square$ & $\square$ & $\square$ \\
\hline & Maintenance Function & & & & & \\
\hline 1. & My Organization Provides Congenial Work Environment & $\square$ & $\square$ & $\square$ & $\square$ & $\square$ \\
\hline 2. & Health And Medical Facilities Has Been Provided & $\square$ & $\square$ & $\square$ & $\square$ & $\square$ \\
\hline 3. & My Organization Has Better Transportation Facilities & $\square$ & $\square$ & $\square$ & $\square$ & $\square$ \\
\hline 4. & Flexible Working Hours Is Properly Maintain & $\square$ & $\square$ & $\square$ & $\square$ & $\square$ \\
\hline
\end{tabular}

\section{Copyrights}

Copyright for this article is retained by the author, with first publication rights granted to the journal.

This is an open-access article distributed under the terms and conditions of the Creative Commons Attribution license (http://creativecommons.org/licenses/by/4.0/). 